\title{
NEGLIGENT INVESTIGATION: \\ A NEW REMEDY FOR THE WRONGLY ACCUSED: \\ Hill V. Hamilton-Wentworth Regional Police SERVICES Board
}

\author{
ERIKA ChamberLaiN
}

\section{INTRODUCTION}

In Hill v. Hamilton-Wentworth Regional Police Services Board,' the Supreme Court of Canada affirmed that the tort of "negligent investigation" exists in Canada." Chicf Justice McLachlin, for the majority, noted that negligent police conduct is "a significant contributing factor to wrongful convictions," and argued that a negligence action was necessary to round out the available remedies for the wrongly accused (previously limited to malicious prosecution, false imprisonment, and misfeasance in a public office). Given the media and public support offered to the wrongly convicted in recent years, the decision in Hill will be generally welcomed. Few would oppose the expansion of compensation for those who have suffered a miscarriage of justice. However, the deferential standard adopted by the Coun leaves room for doubt as to the efticacy of the new tort as a remedy for the wrongfully accused. Although the majority paid lip service to the cause of justice for the wrongly convicted, it is not clear that Hill will provoke a noticeable change in police practices or increase the probability of recovery for plaintiffs. Thus, while it is a step forward in the pursuit of police accountability, it is not the magic solution that society seeks. If anything, it points to the inadequacy of tort law as a means of addressing wrongs within the justice system.

\section{THE. Decision}

The plaintiff, Mr. Hill, was tried and convicted of robbery in the mid-1990s. The evidence against him consisted primarily of eyewitness identification. Although he was eventually acquitted on appeal due to errors made by the trial judge, he had spent 20 months in jail. He sued the police, inter alia, for their alleged negligence in carrying out the investigation against him. The allegations of negligence included: that the police had published a photo identifying Hill as a suspect early in the investigation, thereby tainting subsequent eyewitness investigations; and that the police had lailed to thoroughly investigate information suggesting that other persons might have committed the robberies. Perhaps most egregiously, the police had conducted a photo lineup using Hill (an Aboriginal Canadian) and II Caucasian foils.

- Assistant Professor. Faculty of I.aw. University of Western Ontario. The author would like to thank Jason Neyers and an anonymous reviewer for their comments and insight. The author has written a much shorter ease note for the Law Quarterly Review: "Negligent Insestigation: The Lnd of Malicious Proseculion in Canada?"” (2008) 124 LaW Q. Rev. 205.

2007 SCC 41, [2007] 3 S.C.R. 129 [Hill].

: Negligent investigation had betn accepted as a tort by the Ontario Count of Appeal in Becksfecod $\mathrm{s}$. Outaw (Chicf of Police) (1997). 37 O.R. (3d) 62, a case which received surprisingly little notoriety prior to Hill.

$1 \quad$ Hill, supro note 1 at para. 36. 
It is noteworthy that both eyewitness identification procedures and police "tunnel vision" with respect to a particular suspect have been identificd as primary causes of wrongful conviction. Thus, Hill was a textbook case of how negligent police practices can lead to wrongful conviction, and it is not surprising that the Supreme Court of Canada was sensitive to the political timeliness of its decision. What is perhaps surprising is that the Court ultimately dismissed the plaintiff's claim on the basis that the police had met the standard of reasonable officers at the time of the investigation. As discussed below, this deferential standard of care may render the new tort useful in only the most obvious cases of negligence. Nevertheless, the majority recognized that blanket immunity for police negligence could no longer be justified, and was willing, at least, to impose a duty of care toward suspects under investigation.

Hill being a novel case, the Court analyzed the duty of care based on the revised Amns test they had set out in Cooper v. Hobart' and revisited in Childs v. Desormeanx. "The test was set out in Cooper as follows:

At the first stage of the smms test. two questions arise: (1) was the harm that occurred the reasonably foresecable consequence of the defendant's act? and (2) are there reasons, molwithstanding the proximily belween the partics established in the first part of this lest, that fort liability should not be recognized here? The proximity analysis involved at the first stage of the Anns test focuses on factors arising from the relationship between the plaintiff and the defendant. These factors include questions of policy, in the broad sense of that word. If foreseeability and proximity are established at the first stage, a prima facic duty of care arises. At the second stage of the $A m$ sest, the question still remains whether there are residual policy considemations outside the relationship ol' the parties that may negative the imposition of a duty of carc.... [W] think it useliul expressly to ask, before imposing a new duty of care, whether despite foreseability and proximity of relationship. there are other policy reasons why the duty should not he inupesed.

Thus, the $A m n s / C o o p e r$ test has two main stages: first, the Court examines the foreseeability of harm and the proximity between the partics, which may give rise to a prima facie duty of care; second, the Court looks at residual policy considerations that might negate that prima facie duty. The Court in Hill followed this framework to determine if police officers owe a duty of care to suspects under investigation.

The so-called "proximity" requirement of the Amms/Cooper test has been notoriously difficult to describe. For example. Lord Bridge wrote in Caparo Industries Plc. v. Dickman:

[T] necessary to give them utility as practical tests, but amount in effect to little more than convenient labels to attach to the features of different specilic siluations which ... the law recognises pragmatically as giving rise to a duty of care of a given scope.

See Bruce Maclarlane, "Convicting the Innocent: A Triple Failure of the Justice Systemo" (2006) 3 Man. L.J. 403, lior a helpful stumnary of international inquiries into wronglul conviction over the past century. The discussion of eyewitness misidentitication can be lound starting at $\mathbf{4 4 5}$.

2001 SCC 79. [2001] 3 S.C.R. 537 [Cooper].

2006 SCC 18, [2006] I S.C.R. 643 [Childs].

Cooper, supro note 5 at para. 30. McLachlin C.J.C. and Major J.

[1990] 2 A.C. 605 at 618 (H.L.). 
Unfortunately, readers hoping for clarification of the nebulous proximity requirement will be disappointed by the majority's decision in /lill. The majority stressed two main factors in its proximity analysis: (1) the interests at stake for the plaintiff ("his freedom, his reputation and how he may spend a good portion of his life"), and (2) whether the relationship could be described as "personal." With respect to the latter, the majority made several equivocal statements. For instance:

A sulliciently clone and direct connection between the actions of the wrongdoer and the victim may exist where there is a personal relationship between alleged wrongdoer and vietion. Ilowever, il may also exist where there is no personal relationship between the victim and wrongdoer. ${ }^{10}$

In the next paragraph, the majority wrote the equally unhelpful, "[w] determinative, the presence or absence of a personal relationship is an important factor to consider in the proximity analysis." " The majority never defined what they meant by the term "personal," though it seemed important that the suspect had been singled out at that point in the investigation. They summarily concluded that the "relationship between the police and a suspect identified for investigation is personal, and is close and direct.":

At the second stage of the Amms/Cooper analysis, the majority found that the various policy considerations raised to negate the prima facie duty of care were no more than speculative. They found that the level of discretion excrcised by police was no greater than that exercised by other professionals, and did not exempt them from judicial scrutiny. In addition, there was no compelling evidence that the imposition of a duty of care would have a chilling effect on police investigations, or that it would open the floodgates to claims by factually guilty parties who were acquitted on so-called technicalities. While McLachlin C.J.C. admitted that the tort system might not be perfect. and that some factually guilty parties might recover against police, she found that the potential for abuse was no greater than for other torts. For example, a plaintiff "who recovers against her doctor for medical malpractice may, despite having proved illness in court, have in fact been malingering." Moreover, McLachlin C.J.C. contended that potential abuses would be largely staved off by a temperate standard of care. Indeed, such a temperate standard was enough to dismiss the claims against the police in Hill.

The discussion ol policy factors under stage two of the Amis/Cooper test is perhaps the most satisfying aspect of the majority's decision. Unlike their counterparts in other Commonwealth jurisdictions, the majority were not persuaded by vague claims about defensive policing and the need for discretion in police investigations. They reviewed empirical studies and found that there was no convincing evidence of a chilling effect, and they were not prepared to reject the duty of care based on sheer speculation. ${ }^{14}$ This is undoubtedly preferable to the English approach to cases of police or prosecutorial negligence, where defendants ${ }^{*}$ arguments at the policy stage of the duty analysis have been

Hill, supro note I at para. 34.

thid. al para. 29.

thid. at para. 30 .

lbid. at para. 33.

lbid. al para. 63.

lbid at para. 57 . 
accepted without question. For instance, in Elguzouli-Dafv. Commissioner of Police of the Merropolis, ${ }^{\text {is }}$ Steyn L.J. (as he then was) was easily convinced of the trouble that would ensue if the Crown Prosecution Service (CPS) were saddled with a duty of care:

\begin{abstract}
In my view, such a duty of care would tend to have an inhibiting effect on the discharge by the C.P.S. of its central function of prosecuting crime. It would in some cases lead to a defensive approach by prosecutors to their multifarious duties. It would intredluce a risk that prosecutors would act so as to protect themselves Irom claims of negligence. The C.P.S. would have to spend valuable time and use searee resources in order to prevent law suits in negligence against the C.P.S. It would generate a great deal of paper to guard against the risks of law suils. The time and energy of C.P.S. lawyers would be diverted from concentrating on their prime function of proseculing offenders. That would be likely to happen not only during the prosecution process but also when the C.P.S. is sued in negligence by aggrieved delendants. The C.P.S. would bo constantly enmeshed in an avalanche of interlocutory civil proceedings and civil trials. ${ }^{16}$
\end{abstract}

Lord Justice Steyn provided no evidence for this conclusion, and assumed that all suspects who were exonerated would subsequently commence civil proceedings. This assumption ignores the reality that most suspected criminals lack the financial resources to pursue lengthy civil litigation against the state. and that most are probably relieved to be rid of the justice system once they are found not guilty. While there might be some suspects who abuse the system (as McLachlin C.J.C. conceded in $\mathrm{Hill}^{\text {}}{ }^{2}$ ), this possibility does not seem to justify a blanket denial of the duty of care. Further, as again noted by the majority in Hill, any concerns about the courts second-guessing the exercise of police discretion can be addressed in terms of the standard of care. ${ }^{18}$

The Supreme Court's increased skepticism at the second stage of the duty analysis is to be welcomed. Given the recent trend of the Court to interpret foreseeability and proximity more restrictively, ${ }^{11}$ it is only fair that the defendant's arguments for negating a duty of carc be treated with similar scrutiny. The Court seems to be moving toward a more thorough analysis of all the aspects of the duty of care. And while there may be disagreement about the outcome of the analysis, it is comforting to see that the various arguments have been evaluated, and not merely asserted as fact. Additionally, a more thorough analysis at each stage of the Ams/Cooper test will assist future litigants in identifying the types of arguments that can be raised at each stage, as well as the types of evidence necessary to substantiate those arguments.

[1995] 2 W.L.R. 173 (C.A.).

thid. in 183

Sitpras nole I at para. 6.3.

thid. al para. 56.

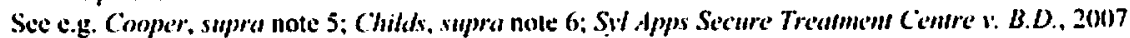
SCC 38, [2007] 3 S.C.R. 83. See also Jason W. Neyers \& Una Gabic, "Canadian tur law since Cooper

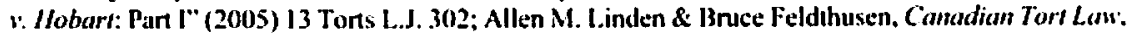
8th ed. (Markham: LexisNexis Buttenworths. 2006) at 294-301: Lewis Klar. Q.C., "The Tort Liability of the Crown: Back to Canada v. Saskaltehewan Wheat Pool" (2007) 32 Advocates' Q. 293. 


\section{WERE THERE GOOD REASONS FOR POI.ICE IMMUNITY FOR NEGLIGENT INVESTIGATION?}

Unfortunately, not every aspect of the majority's decision in $\mathrm{Hill}$ is as thorough as it could be. The majority's reasoning is rather scant in its explanation of why the historical police immunity for negligent investigation should be lifted. This lack of explanation is especially troubling because the introduction of a negligence action has significantly downgraded the level of fault required to bring suit against the police for their conduct in a criminal investigation. Plaintifts had previously been limited to the torts of false imprisonment, malicious prosecution, and misfeasance in a public office, all of which entail a finding that the police have abused their powers in some way. However, McLachlin C.J.C. commented that these existing tort remedies "do not provide an adequate remedy for negligent acts," and that "an important category of police conduct ... will go unremedied if a duty of care is not recognized." investigation was necessary "to complete the arsenal of already existing common law and statutory remedies."21

Conspicuously absent from McLachlin C.J.C.'s decision is an analysis of why a suspect's potential claims were previously limited to false imprisonment and malicious prosecution. The pursuit of criminal justice has typically been seen as of such high importance that those engaged in investigations were granted the latitude to make mistakes. ${ }^{22}$ In order to encourage them to conduct investigations thoroughly, leaving no line of inquiry unexamined, police were granted immunity in negligence in the event that their suspicions were erroneous. As Lord Bridge argued in Calveley v. Chief Constable of the Mersevside Police.

all other considerations apart, it would plainly be contrary to public policy. in my opinion. to prejudice the fearless and eflicient discharge by police of ficers of the vir vially important public duty of investigating crime by requiring them to act under the shadow of a polential action for diumages for negligenee by the suspect. ${ }^{23}$

It is a reality of criminal investigation that some suspects turn out to be innocent. Sometimes this is discovered at the preliminary stages of investigation, but other times it is not discovered until after charges have been laid or even after the suspect has been acquitted. Historically, all of this was seen as the justice system at work: a suspect's exoneration at trial or on appeal meant that the judicial system was doing its job. ${ }^{24}$

Accordingly, there had been a deliberate limitation of liability to circumstances where the defendant had acted for an improper purpose: malicious prosecution requires the plaintiff to prove that the defendant acted without reasonable and probable cause and with a purpose other than carrying the law into effect. ${ }^{25}$ Thus, the Supreme Court of Canada stated in Nelles

3) Hill. supra note 1 al para. 35.

$\therefore$ Hid.

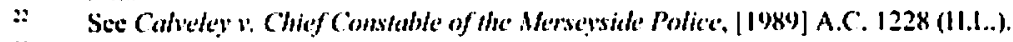

$2 \quad$ Hidl. at 1238 .

it See ibid., where Lord Bridge reasoned that such an exoneratcd suspect has not sulfered any loss that is compensable in tort.

$\because \quad$ John G. Fleming. The Law of Torts, Sth ed. (Sydney: Law Book, 1977) at 598, als adopted by the Supreme Court of Canada in Velles, infro note 26. 
v. Omario $0^{26}$ that a plaintiff bringing such a claim "las no easy lask."27 The Court in Nelles stressed the "hedging devices" inherent in malicious prosecution which serve, in the words of John G. Fleming, "to deter this kind of litigation and protect private citizens who discharge their public duty of prosecuting those reasonably suspected of crime."2x Apparently, at the time of Nelles, the Court saw a need to restrict liability to cases where there was some subjective blameworthiness.

Yet, in /lill, this limitation on liability was viewed as a denial of justice. The claim for negligent investigation was considered necessary to complete the set of remedies available to suspects. It can reasonably be assumed, however, that the negligence claim will not simply fill a gap in the law, but will effectively supplant the existing tort actions. Given the difficulties that accompany actions for malicious prosecution, particularly the requirement of proving the absence of reasonable and probable cause, a plaintiff would be ill-advised to plead that tort rather than negligence. By claiming in negligence, the plaintiff would be relieved of proving the troublesome mental aspects of malicious prosecution. We can therefore expect malicious prosecution to fade in importance in Canada, at least in claims involving the police. Like so many other areas of tort law, actions against police in the investigatory process will presumably be overtaken by the staggering march of negligence."

This development was perhaps inevitable in light of Oniel v. Toronto (Metropolitan) Police Force, ${ }^{j i}$ a malicious prosecution action in which the Ontario Court of Appeal found that malice could be inferred from a lack of reasonable and probable cause. If there were no objective grounds on which to conclude that the plaintiff was guilty, then (it was argued) the police must necessarily have brought the charges against him for some improper purpose. Essentially. Oniel subsumed the subjective element of malice within the objective test of reasonable and probable cause, and thereby moved malicious prosecution closer to the objective fault standard in negligence. Hill has simply completed the transition to negligent investigation, and to its credit, maintains a greater degree of transparency about the change in the basis of liability. Rather than distorting the mental elements of malicious prosecution such that they cease to require subjective blameworthiness, Hill has reoriented the fault requirement around the objective standards of negligence law.

This development also rellects the changing nature of criminal investigations. Many of the "hedging devices" in the tort of malicious prosecution were initially established to protect citizens involved in private prosecution. At a time when the system relied on private citizens to prosecute alleged criminals, it was necessary to protect them from liability if the prosecution turned out to be unsuccessful. Perhaps now, with private prosecutions being all but obsolete, the need for such restrictions on liability is diminished. Paid law enforcement officers do not require an incentive to investigate crime, and it is diflicult to justify their immunity from suit when their conduct falls below the standard of reasonable officers and a plaintiff is wrongly accused as a result.

[1980] 2 S.C.R. 170 [Ne/les].

Ihid. ill 194. Lamer J.

lileming. supra note 25 at 600.

Sec Tony Weir, "The Staggering Warch of Negligenee" in Peter Cane \& Jane Stapleton. eds.. The Law of Obligations: Essans in Celebration of Johm Fleming (Oxford: Clarendon Press, 1998) 97.

(2000), 195 D.L.R. (4th) 59)(Ont. C.A.) [Oniel]. 
It remains to be seen whether negligent investigation will be limited to actions against the police, or whether it will extend to Crown prosecutors as well. In Nelles, the Supreme Court of Canada found that Crown prosecutors could be sued for malicious prosecution; however, the Court was careful to stress that this did not affect their immunity for "error in judgment or discretion or even professional negligence." While barristers" immunity has recently been croded throughout the Commonwealth." it is not clear that the trend extends to criminal prosecutors. ${ }^{33}$ It may well be that the degree of discretion exercised by prosecutors. combined with their duties to the Crown, will protect them from negligence liability for the good laith exercise of their prosecutorial functions.

\section{The RANGe OF Duties OWE.d hy POLICE}

In recognizing a duty of care toward suspects, Hill has added another layer to the duties owed by police. As discussed below, Canadian police already owe a private law duty of care to potential victims of crime in some circumstances. In addition, they owe a general duty to the public to prevent crime and bring charges against suspected criminals. The majority in Hill did not fully explore the implications of introducing a private law duty of care toward suspects: in particular, whether this new duty would contlict with the existing public and private duties owed by police, and if so, which duty should take precedence.

\section{A. Private Law duties Owed by Police TO POTENTIAL Victims of Crime:}

The Canadian courts are already somewhat unique in the Commonwealth in imposing a duty of care toward potential victims of crime. In Jame Doe v. Toromo (Merropolitan) Commissioners of Police, ${ }^{34}$ the police were found to owe a duty of care to a woman atlacked by a serial rapist. Because all of the attacks had occurred in a small geographical area, and the victims had all occupied second- or third-floor apartments with accessible balconies, MacFarland J. concluded that the police owed a duty to warn or protect women in the area from a potential atlack.

This is in sharp contrast to the English position, where courts have declined to impose a duty of care toward victims of crime. In I/ill v. Chief Comstable of West Yorkshire, "is the House of Lords denied a claim on behalf of the last woman killed by the so-called Yorkshire Ripper. It had been argued that. had the police not been negligent in their investigation, the serial killer would have been captured earlier and would not have killed Ms. Hill. The House of Lords based its decision, in part, on a lack of proximity. Lord Keith noted that the plaintilf" "was one of a vast number of the female general public who might be at risk from [the killer's] activities but was at no special distinctive risk in relation to them."

" Villes, supra note 26 at 190, L.amer $J$.

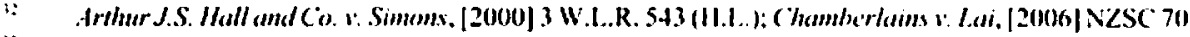

3) The Canadian courts hase previously liound that (rown prosecutors are immune in negligence: (ievomon

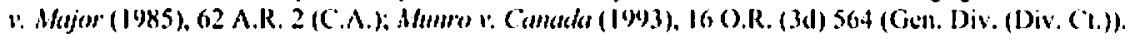
(1998), 39 O.R. (3d) 487 (Ct. J. (Cich. Div.) [. Fame Dac'].

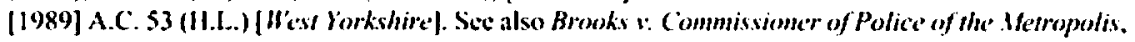
[2005] UKHL. 24: Smith r: Chief Constable' of Sussex l'olice. [2008] UK!l1. 50.

in Nest rorkshire, ibid. al 62 . 
class of victims was too large and undetermined to place Hill in a legally proximate relationship with the police.

The English courts have also denied claims in cases where a criminal has identified a particular target. Most notoriously, in Osman v. Ferguson, ${ }^{37}$ the plaintiff's schoolteacher had threatened him and his family, and the police were aware of his harmful intentions. The teacher ultimately injured the plaintiff and killed the plaintiffs father, but the Coun of Appeal, relying on W'est Yorkshire, rejected his claim against the police. While both the offender and the victim(s) were identifiable in Osman, such that there was much greater proximity, the duty of care was rejected on policy grounds.

Among the policy reasons cited by the English courts for denying a duty of care in the above cases was that it might conflict with the duties police owe to the general public. As Lord Templeman argued in West Yorkshire, the police must excrcise discretion in prioritizing their investigations. Il police are found to owe a duty to potential victims, their priorities will always be under scrutiny: "Ti]f the policeman concentrates on one crime, he may be accused of neglecting others. If the policeman does not arrest on suspicion a suspect with previous convictions, the police force may he held liable for subsequent crimes." ${ }^{38}$ Thus, the English courts have concluded that, because police owe duties to the general public, and have discretion about prioritizing and carrying out investigations, they do not owe a private law duty of care to any particular victim if a perpetrator is not apprehended or charged in a timely fashion.

\section{B. Private law Duties OWed by Police TO Pote.vTIAI. Suspects}

For reasons similar to those discussed above, most Commonwealth courts have found that police do not owe a duty of care to those suspected of crime. In Cran v. State of New Somth Wakes, ${ }^{39}$ the Court negated such a duty on policy grounds, even though the plaintiff in that case was clearly vulnerable to police negligence and there was no apparent conflict with public duties. The plaintiff was in custody and could have been released if the authorities had properly filled out the forms to expedite an analysis of a substance they thought to be LSD. but which tumed out to be paper stickers. Yet, Santow J. reasoned:

Lven ministerial tasks involve decisions as to priorities in the deployment of resources... If the Police were for fear of civil action to employ additional resources to check that forms were properly filled out ... that may well involve an allocalion of resources away from active police enforcement to administration."

Accordingly, even in cases where the duty to suspects seems consistent with the general public interest, the Commonwealth courts have rejected a duty of care based on conflicts inherent in resource allocation. 


\section{The Potential, for Confi.ictinc; Dutiss}

The issue of conflicting private and public duties has, therefore. been heavily stressed by the Commonwealth courts when examining allegations of police negligence. In contrast, the majority in $\mathrm{Hill}$ engaged in a rather cursory analysis of the potentially conflicting duties owed by police to suspects. victims, and the general public. With respect to victims, the majority sidestepped any potential conflict by casting indirect doubt on the validity of.Jame Doe, ${ }^{41}$ and by stating that an analysis of the duty owed to victims would have to wait for another case. With respect to public duties, the majority reasoned that a police officer's duty to investigate crime is already constrained by various factors, including the Criminal Cock ${ }^{42}$ and the Canadian Charrer of Rights and Freedoms. ${ }^{43}$ Chief Justice McLachlin also denied that there was a conflict between the public interest and the interests of a potential suspect: "[i]ndeed, the suspect is a member of the public. As such, the suspect shares the public's interest in diligent investigation in accordance with the law."

While this statement may be technically truc, it is surely disingenuous to suggest that there is no conflict between the public interest and the interests of a potential suspect, especially if we keep in mind that some potential suspects are, in fact, guilty. Guilty suspects would probably prefer for the police to not be diligent in their investigation of crime, as this decreases the likelihood of their arrest and conviction. Moreover, even in a diligent investigation, it is inevitable that innocent suspects will sometimes be investigated. Even if no charges are brought against them, these innocent suspects will suffer some psychological stress, damage to reputation, and even financial loss as a result of the investigation. This was recognized by Charron J., who wrote for the dissenters in Hill:

\footnotetext{
[E] ven in those cases where the imnoent suspect is exonerated as a result of the investigaticn. he or she will inevitably have suffered some harm as a result of the process that led lo his cxoneration: her reputation may be tamished, or she may have suffered econonic loss. This is why I say that all suspects, whether they have in fact committed the oflence or not, stand to lose from being targeted by the police. It is alwais in the suspect's personal interest to be left alone by the state. 4 "
}

Indeed, it would seem an unusually noble person who welcomes being targeted by a criminal investigation for the sake ol the public interest. The dissenters were undoubtedly correct in describing the majority"s view as naïve. "The interests of the public and an innocent suspect are not synonymous.

The potential conflicts between the duties owed to suspects and to victims of crime are perhaps even more acute. Again, the dissent provided a much more thorough analysis of this issue than the majority. Justice Charron disagreed with the Ontario Court of Appeal's

Chicf Justice Melatelin stressed that Jeme Dece was merely a lower court decision and was "of little assistance in the case at bar" (IIill, supro note 1 it para. 27).

$\therefore \quad$ R.S.C. 1985, c. C.4to.

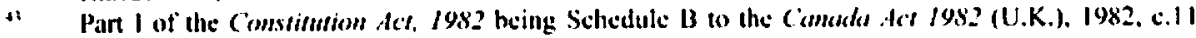
[Charfer].

H. Hill, stupra nole I at para. 41 .

15. Ibid. al para. 132 [emphasis in original).

ath bid. 
assertion that there was a general duty of care owed by police to victims of crime; ${ }^{47}$ however, sle seemed prepared to accept that, where a particular victim or group of victims is at a specific risk of harm, the police may have a duty to protect those victims or at least inform them of the potential danger so that they can protect themselves. ${ }^{4 k}$ Accepting this narrowlydefined duty, Charron J. went on to explain a "crucial distinction" between victims and suspects in terms of the duty of care: while "the public interest in having police officers investigate crime for the purpose of apprehending offenders and a potential victim's interest in being protected from the offenders are generally reconcilable," the duty "to investigate crime and apprehend offenders is diametrically opposed to the interests of the person under investigation." This suggests that, if any private law duty is to be imposed on the police. it should be toward targeted victims of crime, rather than toward suspects.

Nevertheless, as a result of the majority's decision in $\mathrm{Hill}$, police now owe a duty of care to both potential victims and suspects. ${ }^{50}$ Intuitively. one would think that there is a real tension between these two duties of care, as they represent two constituencies witl competing interests in the criminal justice system. Domestic abuse cases provide a simple illustration of this tension. $A$ s indicated. the dissent in / $/ \mathrm{il} /$ was prepared to accept that police owe a duty of care to an identifiable victim who is clearly at risk. A woman who has reported domestic abuse is clearly identifiable, as is her abuser. Moreover, there is a significant risk of recurrence. Thus, there seems to be sufficient proximity to find a duty of care. ${ }^{\text {st }}$ Further, there are some jurisdictions in which the police are required, as a matter of official policy, to take some action against the alleged abuser. "Such policies were primarily recommended to counter the historical tendency of police to discount claims of domestic abuse. ${ }^{53}$

However, now that police have been found to owe a duty of care to suspects, such policies will need to be reconsidered. $A$ man who is unjustly accused of domestic abuse may be subject to psychological stress, stigma, and disruption of employment and family life. It may be considered institutionally negligent to arrest suspected abusers based on nothing more than a partner's complaint. ${ }^{54}$ Thus, police could be caught between their duty to protect abused women and their duty to diligently investigate before taking steps against a suspect. If police take no action, they risk being sued by the woman if the abuse continues.

In B.M. r. British Columbia (.A.C.), 2004 BCCA 41)2, [2004] 10 W.W.R. 286, the Coun acknowledged that police might owe a duty of care to a victim of domestic abuse. The plaintiff sued police after her estranged husband, a known violent oflender, broke into her home and shot her friend to death. Her claim was sucecsslul at trial, but dismissed by the Court of Appeal on the issue of causalion. The Court reasoned that, human behaviour being unpredietable, it was not established that the attack could have been prevented by the police.

" For critical reviews of such policies. sec Linda (j. Mills. "Mandatory Arrest and Prosecution Policies for Domestic Violence: A Critical Literature Review and the Case for More Research to Test Vietim I:mpowerment Approaclies" (1998) 25 Criminal Justice and Behavior 306: Carolyn Hoyle \& Andrew Sanders, "Police Response to Domestic Violence: From Victim Choice to Victim Limpowerment?" (2000) 40 Bril. J. Crim. 14.

$\therefore \quad$ bid

4 Sec e.g. Jensemv. Stemmer. 2007 MBCA 42 (2007), 282 D.L.R. (4th) 340, where il was unsuccesslully argued that a "zero tolerance" policy for domestic violence could give rise to punitive damages in a claim for wrongfill imprisonment. 
Conversely, if police take action too quickly. they may be sued if the man faces charges that are later dropped. Granted, the courts will likely show deference to police in terms of the standard of care applied in these situations. The potential for conflict between the duties to victims and to suspects is, nevertheless, present. and should at least have been acknowledged by the majority in $\mathrm{Hill}$.

In addition, numerous police forces operate under budget and/or personnel shortages, which are exacerbated by an increasing amount of paperwork." The reality of resource allocation in police work dictates that some investigations receive more attention than others. Some suspects may not be apprehended as soon as they could be. Others are apprehended when the evidence against them is less than conclusive. The system is not ideal for victims. suspects, police, or the general public.

All this is to say that the issue of conflicting duties is not as cut and dry as the majority in $\mathrm{Hill}$ made it out to be, and deserved a more thorough analysis. It will probably not be long before a case emerges where the duties of care owed to suspects and victims come into direct conflict, and the court will need to decide how to reconcile police duties. It would therefore have been helpful for the majority in Hill to more methodically explore the potentially conflicting duties, rather than baldly state that the conllict is "doubtful" or "tenuous."

$1 t$ is another question, however, whether the potential for conflicting duties should render police immune from negligent investigation. Police are not the only professionals who are required to balance competing interests and make discretionary decisions. In the modern health care system, physicians are often required to prioritize patients and make judgment calls about the appropriate use of scarce resources. But this does not lead to immunity if their actions fall below the standard of a reasonable physician in the circtumstances." Thus, as long as the courts maintain a deferential stance in terms of the standard of care. there is no reason for police to fear that their discretion will be constantly second-guessed. Police wil] effectively, through the "reasonable officer" standard. set their own standard of conduct. Further, in light of increased awareness of the risk of wrongful conviction, it is difficult to justify the continued immunity of police in negligence.

\section{THE UTILITY OF NEGI.IGENT INVESTIGATION AS A REMEIOY FOR THE WRONGI, CONVICTED}

Underlying the majority's decision in Hill is a desire to obtain justice for the wrongly convicted. Chicf Justice McLachlin made reference to the recent judicial inquiries into high-

" See Charlie Gillis. "The Mounties give up" Meckom s (1 February 2006), online: Macleans.ca <http:// www.macleans.ca/article.jsp?content=20060130_120538_120538\&source- srch>: "Mountic shortage prompts Manitoba RCMP lo bust recnuiting" (CBC Nows (30) August 2006). online: CIBC News Chtip://www.cbe.ca/news/story/2006/08/30/rcmp-recriththol "Rural Sask. leaders worricd about Mountic shortage" CBC News (15 February 2008), online: CBC News hotp:/www.cbe.ca/canadat saskalchewan/siory/2008/02/15/rcmp-rural.html?.

"hill. sitpra note 1 at paras. $40-41$.

s: Sece e.g. Jinks : Carchell (1987), 3 A.C.W.S. (3d) 357 (Ont. H. (t. J.), afl`d in part [1989] O.J. No. 1492 (C.A.)(QL): Lan Estate v: Simice(1994). 47 A.C.W.S. (3d) 1206 (B.C.S.C.): Batemam 1: Doiron (1993), 141 N.B.R. (2d) 321 (C.A.). 
profile wronglul convictions ${ }^{5 x}$ and was eager to fill the gap in the existing range of tort remedies. This cagerness is not surprising, given the general public sympathy toward the wrongly convicted. The majority was, no doubl, aware that the issue is politically sensitive. and presumably recognized that a finding of blanket immunity for the police would not be well-received. Moreover, given the racial undertones of the police conduct in $/ \mathrm{ill}$, and the fact that Aboriginal Canadians are incarcerated at a disproportionate rate, ${ }^{59}$ the majority's decision on the duty of care was quite predictable.

What was more surprising about the majority's decision, however, was the deferential stance it adopted with respect to the standard of care. Chicf Justice McLachlin adopted a standard of "the reasonable police oflicer in like circumstances," and lound that it should reflect "the realities of police work." Among other things, the standard of care should reflect that, at the early stages of investigation, police may be required to act on "little more than hearsay, suspicion and a hunch. ${ }^{* 1}$ Chief Justice McLachlin summarized:

\footnotetext{
The standard ... is that of a reasonable officer, judged in the circumstances prevailing at the time the decision was made - circumstanes that may include urgency and deficiencies of information. The law of thegligence dees not require perfection of professionals; nor dices it guarantec desired results. Rather, it aceepts that police officers, like other professionals, may make minor errors or errors in judgment which cause unfortunate results, without breaching the standard of care."
}

This standard is eminently sensible. The courts cannot. with the benefit of hindsight and the time necessary to reach an optimal course of action, judge the conduct of police, who do not always have such luxury. It is appropriate to offer some deterence to police discretion in the heat of an investigation.

The application of the standard of care in Mill was relatively generous to the deliendants. The majority prefaced its analysis with the statement that police practices have improved since the investigation occurred in 1995, and that the defendants' conduct should be judged by the standards prevailing at that time. ${ }^{63}$ With respect to the photo lineup (which was comprised of Hill and 11 Caucasian foils), the majority accepted the trial judge's finding that there were no rules regarding lineups in 1995. While a modern day police officer would likely use foils of the same race as the suspect. the defendants' conduct was not unreasonable in its day. ${ }^{\text {th }}$ This conclusion will sit uneasily with some observers: it seems almost a matter of common sense that the foils in a photo lineup should be the same race as the suspect. Nevertheless, some of the foils had similar skin tones and facial features to Hill, so his race did not make him obviously stand out. On the facts, the trial judge and the majorities of the

Jill. supra note I at para. 186.

See Canadian Criminal Justice Association. Aboriginal Pcoples and the Criminal Justice Sistem

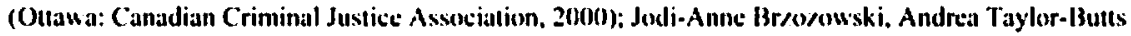
\& Sara Johnson. "Victimization and offending among the Aboriginal population in Canada" (2006) 26:3 Juristal 1.

IVill. supra note 1 at paras. $67-68$.

Ibid. at para. 68.

Jbid. at para. 73 [footnoles omilted].

Jbid. at para. 77.

lbid. at para. 80. 
Court of Appeal and Supreme Court all concluded that the racial composition of the lineup did not result in unfaimess.

The other main allegation of negligence in $\mathrm{Hill}$ was that police downplayed evidence that another perpetrator might be responsible for the crimes. They arrested and charged Hill cven though they had tips implicating two other men, and then proceeded with the case against him even though the robberies continued while he was in custody. Alhough another suspect was identified and charged with some of the robberies, the detective in charge did not seek to delay Hill's trial to permit further investigation. Chief Justice McLachlin conceded,

[h]ad Detective Loft conducted turther investigation, it is likely the case against Hill would have collapsed. Had he re-interviewed the eyewitnesses, for example, and shown then [the other suspect s] photo. it is probable that matlers would have curned out otherw ise: when the witnesses were eventually shown the photo of [the other suspect], they recanted their identification of litll as the robber.",

To the average lay reader. it may seem negligent to proceed with a trial against an accusced in the face of evidence that someone else might be responsible. At least, it would seem prudent to confront the eyewitnesses with the other suspect before allowing them to testify against the accused. Yet, McLachlin C.J.C. found that the delective's conduct fell within the acceptable range of police discretion. "She stressed that, in 1995. "awareness of the danger of wrongful convictions was less acute than it is today. "Thus, the majority concluded that the detective met the standard of a reasonable officer in the circumstances.

This highly deferential standard, and the wide latitude afforded to police discretion, raise questions as to the ultimate utility of the tort of negligent investigation. If the lower courts follow the Supreme Court's lead. plaintiffs will only be successful in the most obvious cases of police negligence. Further, given the importance of loyalty and mulual support within the profession, ${ }^{\text {tx }}$ there is reason to be skeptical whether police will be willing to testify that a fellow officer's conduct fell below the standard of care. $\Lambda$ s a result, it is doubtful that negligent investigation will be the vehicle of justice for the wrongly convicted that the majority professed it to bc.

This renews the debate about whether the tort system, in general, is the best way to effect compensation for wrongful conviction." Civil litigation is notoriously slow, expensive and uncertain. "Further, it seems cruel irony that a person who has spent months or even years trying to clear his name in the criminal courts should now be forced to seek compensation in the civil courts. Given the documented psychological trauma that accompanies wrongful

o5. Ibid. al para. 83.

m losd. all para. 88 .

(b) Ibid.

s. Sec Jerome H, Skolnick. "Corruption and the Bluc Code of Silence" (20)2) 3 Police Pratetice and Rescarch 7.

a) See H. Archibald Kaiser, "Wrongful Conviction and Imprisunment: Towards an End to the Compensatory Obstacle Course" (1989) 9 Windsor Y.B. Access Just. "6.

io See Peter Cane, Ativah s Accidents, Compensation and the Law, 7 th cd. (Cambridge, U.K.: Cambridge Universily Press. 2(106). 
conviction." it is unlikely that many eligible persons will have the strength or desire to pursue a civil remedy. Moreover, compensation would still depend on the plaintiff being able to establish police negligence and show that such negligence caused the wrongful conviction - two hurdles which may well be difficult to overcome. Thus, most persons who are wrongly convicted will still rely on the system of ex gr'atia payments that has been the main source of compensation in Canada to date. ${ }^{2}$

Inslead. the new tort of negligent investigation seems of greatest utility to those who have been acquitted or had their charges dropped at some time prior to conviction, who still have the financial and psychological resources to pursue a civil claim. Since these suspects were not convicted, they have not suffered a "miscarriage of justice" in the sense that we normally associate with wrongful conviction, and they do not have access to the extraordinary Criminal Code provisions relating to wrongful conviction. ${ }^{73}$ Still, they have suffered the economic and emotional harms of a criminal trial, and may wish to seek compensation if they discover that those harms could have been avoided by a more adequate police investigation.

On this front, however, the dissenting justices were concerned that the new tort of negligent investigation might be over-inclusive. Justice Charron warned that a finding of "not guilty" in a criminal trial does not neecssarily mean that the accused was factually innocent. The accused might have been acquitted due to Charrer violations, weaknesses in the chain of evidence, or inconsistencies in witness testimony. The onerous requirements of the Charter and the criminal burden of proof help to protect against wrongful conviction, under the adage that it is better for ten guilty men to go free than for one innocent man to be convicted. ${ }^{77}$ This is justifiable in light of the punishment, stigma, and personal hardship that accompany eriminal conviction. However, as the dissent in Hill pointed out, any accused who is found not guilty will now be a potential plaintiff in a claim for negligent investigation. If he can point to substandard conduct by the police, he can make a claim for compensation. This is in spite of the possibility that he may be factually guilty of the crime. As Charron J. explained,

in the context of a tort action. we must come to terms with the reality that the person who committed the oflence may well stand to benefit rather than lose from a botched-up insestigation. The true victim in such eases is not the suspect but the public at large. Should the successful accused who actually committed the offence be entitled to use the acquittal brought athout by the uegligent conduct of poliec investigators as a basis to claim compensation? ?s $^{3}$

Thus, unless the tort of negligent investigation requires plaintiffs to establish their lactual innocence, there is potential for abuse by factlally guilty parties. At the same time, if such a requirement were adopted, there would be a risk that an innocent suspect would be unsuccessful in his civil action if he could not prove his factual innocence. Justice Charron

"Adrian Cirounds, "Psychological Consequences of Wronglul Conviction and Imprisonment" (2004) 46 Canadian Joumal of Criminology and Criminal Justice 165.

Siupra note (6) at 106.

Supra note 42, ss. 696.1-696.0.

William Blackstone. Commentaries on dhe Lan of England, vol. 4 (Oxlord: Clarendon Press, 1769) al 352.

Iill. supro note I at para. 161 [emphasis in original]. 
conceded. "[m]ecting this burden may prove impossible to do." The dissenters feared that these opposing problems could not be avoided without introducing altemative verdicts such as "factually innocent" or "not proven" into the criminal process, or by injecting the existing "not guilty" verdict with a meaning that it does not currently hold." Either way, this would have profound ramifications in the criminal law context, which might make us hesitant to introduce a new tort.

Granted, similar considerations might arise with respect to the existing tort of malicious prosecution, where a plaintiff need only establish that the proceedings were terminated in his favour. ${ }^{\text {ix }}$ This includes not only a verdict of not guilty, but also withdrawal of the charge at any time prior to the verdict. Theoretically, it is possible for a factually guilty party to recover in malicious prosecution, and thereby benefit from the faulty police or prosecutorial conduct. Nevertheless. given the additional mental elements of malicious prosecution and the "hurdles" inherent in that tort, the possibilities of abuse by factually guilty parties are much slimmer. This reinforces the earlier argument that there may well have been good reason to restrict claims against police and prosecutors to false imprisonment. malicious prosecution, and misfeasance in a public office. When police act maliciously, without reasonable and probable grounds, it is more likely that the accused in the case was factually innocent. Thus, the risk of recovery by factually guilty parties is less severe.

These potential problems in the operation of the tort of negligent investigation suggest that the tort system is not an ideal forum for complaints about wrongful accusation and conviction. There is nothing wrong with introducing a new tort. but it is no panacea. At best. it may provide compensation to those individuals who have the "good" fortune of identifying police negligence as a cause of their wrongful accusation, and who are willing to undertake civil litigation and the problems it entails. But it should not be used as an excuse to forego a more effective public system of review and compensation for those who have sulliered public injustice. ${ }^{30}$

\section{vi. Conci.usion}

The Supreme Court of Canada's decision in $\mathrm{Hill}$ is laudable for introducing negligence liability against the police when no other Commonwealth jurisdiction has done so. In the modern welfare statc. where many public servants work with strained budgets and have to prioritize their tasks, there is no convincing justification to privilege the police by granting them immunity in negligence. Where police conduct falls below a reasonable standard. and as a result, a plaintiff suffers the harm of being charged, tried, and perhaps even convicted of a crime he did not commit, the plaintill should have a claim for compensation from the negligent actors. Given that any judgment against the police is likely to be paid by the local

\footnotetext{
Ihid. at para. 166.

Sec lhe comments of I.amer J. in R. v: Cirdie, [1985] I S.C.R. 810 at 825.

Nelles, supra nole 26 at 193.

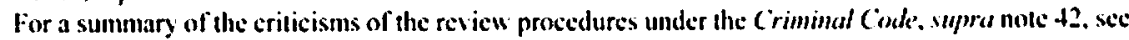
Patricia I3raiden \& Joan Brockman. *Remedying Wrongful Convictions Through Applications to the Minister of Justiec Under Section 690 of the Criminal ( okk" (1999) 17 Windsor Y. B. Acess Just. 3 Although this review was written prior to the 2002 antendments, several of its crilicisms are still applicable to the current process.
} 
police authority under the doctrine of vicarious liability, the action for negligent investigation may provide an indirect means of public compensation in circumstances where there is a general public sentiment that compensation is warranted.

However, while the Supreme Court has introduced this new remedy with much rhetoric about justice for the wrongly convicted, it has perhaps minimized the utility of the new tort by adopting a highly deferential standard of care. Moreover, it is unlikely that the wrongly convicted will take much comfort in the tort of negligent investigation. since civil remedies require such a substantial investment of time and money for a result that is anything but certain. The main benefactors of the new tort will not be the wrongly convicted, but those who are exonerated at some time prior to conviction. Such persons will now have the benefit of a lower fault threshold, and will be relieved of proving the troublesome mental aspects of claims for malicious prosecution. Thus, perhaps the most significant long-term effect of $\mathrm{Hill}$ will be the declining importance of malicious prosecution in Canada. 